\title{
Expression of miRNA-106b in conventional renal cell carcinoma is a potential marker for prediction of early metastasis after nephrectomy
}

Ondrej Slaby ${ }^{1,3^{*}}$, Jana Jancovicova ${ }^{4}$, Radek Lakomy ${ }^{1}$, Marek Svoboda ${ }^{1}$, Alexandr Poprach ${ }^{1}$, Pavel Fabian², Leos Kren ${ }^{5}$, Jaroslav Michalek ${ }^{3}$, Rostislav Vyzula ${ }^{1}$

\section{Correction}

After the publication of this research article [1], the authors noticed an error with Figure 1. Graph D which should have indicated miR-106b expression levels in renal parenchyma (RP) and renal cell carcinomas (RCC), was mistakenly displayed as a duplicate of Graph $\mathrm{C}$. The corrected Figure 1 is provided here.

\begin{abstract}
Author details
'Masaryk Memorial Cancer Institute, Department of Comprehensive Cancer Care, Zluty kopec 7, Brno, Czech Republic. ${ }^{2}$ Masaryk Memorial Cancer Institute, Department of Oncological and Experimental Pathology, Zluty kopec 7, Brno, Czech Republic. 'Babak Research Institute, University Cell Immunotherapy Center, Kamenice 5, Brno, Czech Republic. ${ }^{4}$ Masaryk University, Faculty of Science, Department of Biochemistry, Kotlarska 2, Brno, Czech Republic. ${ }^{5}$ University Hospital Brno, Department of Pathology, Faculty of Medicine, Masaryk University, Brno, Czech Republic.
\end{abstract}

Received: 30 July 2010 Accepted: 6 August 2010

Published: 6 August 2010

\section{Reference}

1. Slaby O, Jancovicova J, Lakomy R, Svoboda M, Poprach A, Fabian P, Kren L, Michalek J, Vyzula R: Expression of miRNA-106b in conventional renal cell carcinoma is a potential marker for prediction of early metastasis after nephrectomy. Journal of Experimental \& Clinical Cancer Research 2010, 29:90.

\footnotetext{
* Correspondence: slaby@mou.cz

'Masaryk Memorial Cancer Institute, Department of Comprehensive Cancer Care, Zluty kopec 7, Brno, Czech Republic
}

Full list of author information is available at the end of the article

Submit your next manuscript to BioMed Central and take full advantage of:

- Convenient online submission

- Thorough peer review

- No space constraints or color figure charges

- Immediate publication on acceptance

- Inclusion in PubMed, CAS, Scopus and Google Scholar

- Research which is freely available for redistribution

Submit your manuscript at www.biomedcentral.com/submit
C Biomed Central 


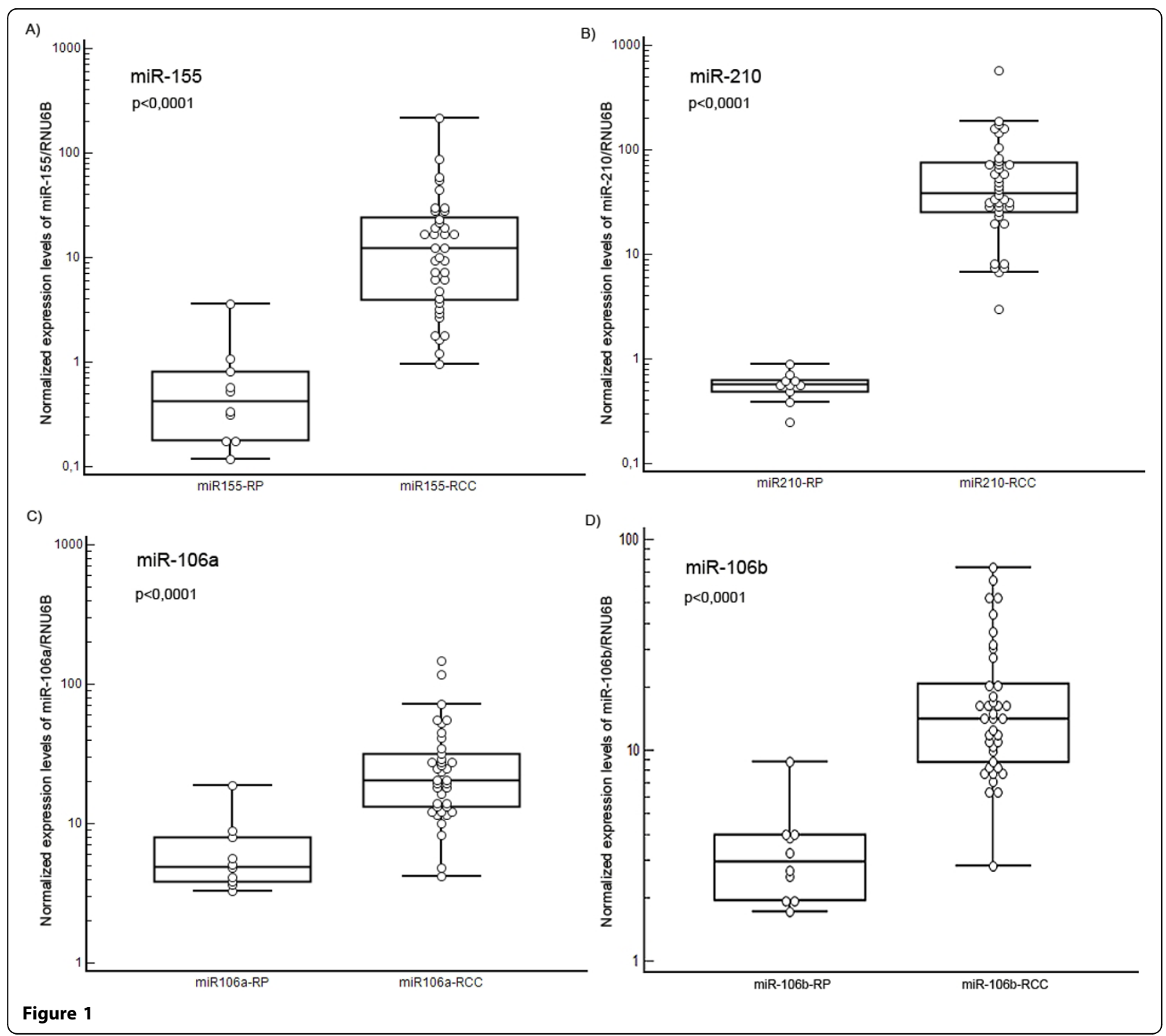

